\title{
Social network analysis as a strategy for monitoring the dissemination of information between hospitals
}

\author{
Análise de redes sociais como estratégia de monitoramento \\ para a difusão de informações entre hospitais
}

\author{
Francisco José Aragão Pedroza CUNHA' \\ Núbia Moura RIBEIRO² \\ Roberto Luiz Souza MONTEIRO3 \\ Hernane Borges de Barros PEREIRA ${ }^{3}$
}

\begin{abstract}
This article explores the structure of connections between the hospitals that are members of a hospital management innovation and learning network. This study was based on the assumption that there are limitations to encourage the communication and diffusion of knowledge between health service organizations if they are not effectively connected through social networks. Social Network Analysis was used as a strategy for monitoring the dissemination of information between hospitals. Theoretical concepts of diffusion of knowledge allowed emphasizing the role of the phenomena and communication and learning processes as the driving forces for health service innovation. The results showed weak interactions between hospitals and a lack of cohesion within the network. Therefore, there is a need for policies to promote the flow of data and information, which requires network openness to foster the exchange of innovative processes. Interactions between these hospitals in horizontal and disseminated structures have yet to be stimulated, established, incorporated, and developed by individuals, institutions and health service organizations.
\end{abstract}

Keywords: Knowledge diffusion. Innovation. Social network analysis.

\section{Resumo}

Este artigo explora a estrutura de ligações entre os hospitais integrantes de uma rede de inovação e aprendizagem em gestão hospitalar. Pressupõe que há limitações para fomentar a comunicação e a difusão de conhecimento entre as organizações prestadoras de serviços de saúde caso não estejam configuradas em redes sociais. Utiliza-se como método a Análise de Redes Sociais, compreendida como uma estratégia para monitorar a difusão de informações entre hospitais. As assertivas conceituais sobre a difusão do conhecimento enfatizam o papel dos fenômenos e dos processos de comunicação e de aprendizagem como a força motriz da propagação de uma inovação nos serviços de saúde. Os resultados revelam uma fragilidade da interação dos hospitais e da coesão deles na rede. Assim, políticas para promover o fluxo de dados e informações são necessárias, requerendo abertura dos componentes da Rede investigada para intercambiar seus processos inovativos. A interação desses hospitais em estruturas horizontalizadas e capilarizadas é uma qualidade ou propriedade ainda a ser adotada, incorporada, assimilada e desenvolvida pelos sujeitos, instituições e organizações de serviços de atenção à saúde.

Palavras-chave: Difusão de conhecimento. Inovação. Análise de redes sociais.

\footnotetext{
1 Universidade Federal da Bahia, Instituto de Ciência da Informação, Programa de Pós-Graduação em Ciência da Informação. Av. Reitor Miguel Calmon, s./n. Vale do Canela (parte superior), Campus Universitário do Canela, 40110-100, Salvador, BA, Brasil. Correspondência para/Correspondence to: F.J.A.P. CUNHA. E-mail: <pedrozaici@gmail.com>.

2 Instituto Federal de Educação, Ciência e Tecnologia da Bahia, Departamento de Química. Salvador, BA, Brasil.

${ }^{3}$ Serviço Nacional de Aprendizagem Industrial, Campus Integrado de Manufatura e Tecnologia, Programa de Modelagem Computacional. Salvador, BA, Brasil.

Received in 30/3/2015, resubmitted on 6/11/2015 and approved in 21/12/2015.
} 


\section{Introduction}

Organizations that innovate depend on their board and staff members' actions towards the increase of their cognitive abilities. The essence of these organizations consists of an intense learning cycle, characterized as the development of individual and collective skills and abilities. This development process enables individuals to gain new perceptions and raise awareness of the reality they experience, which requires communication strategies and dissemination of organizational knowledge.

This research is based on the assumption that there are limitations regarding the development of communication and diffusion of knowledge between health service organizations if they are not effectively connected through social networks. Thus, the empirical approach of this study was the investigation of the relationships between 37 hospitals that are members of a hospital management network called "Innovation and Learning Hospital Management Network (InovarH Network)", which is described in the "Methodological procedures"section.

The objective of this study is to verify whether Social Network Analysis (SNA) can be used as a monitoring strategy for the dissemination of information between hospitals. Therefore, based on SNA, this study identified some aspects of the connections between the InovarH Network hospitals. These aspects are related to collaborative relationships, organizational learning, and management innovation. The network analyses were based on the answers given by the hospitals that signed the Membership Terms of the InovarH Network.

The different applications of concepts and methods the SNA include the analysis of social actors, such as individuals and organizations. These analyses can address the relationships between these actors by measuring factors such as information flows (Matheus \& Silva, 2009). SNA can help to investigate real and practical cases of various types of networks. In the present study, a one-mode network was analyzed observing the relationships between the actors within the context of hospital management. We argue that this type of analysis (SNA) can serve as a strategy for monitoring the dissemination of information between hospitals, more specifically between the Health Care Networks of the Sistema Único de Saúde (SUS, Brazilian Unified National Health System).

Communication processes permeate every phase of human history and, at present, they are used to support the establishment of networks (e.g., human social networks) (Mattelart \& Mattelart, 2003). Human communication can still be seen as a driving phenomenon of the development of the personal domain and shared vision. With regard to the personal domain, communication enables the subject to engage in a dialogue with him/herself and with others; it leads the individual to sources of information and enhances the creation of knowledge (Senge, 2010).

Theoretical concepts of diffusion of knowledge emphasize the role of communication processes as a driving force for propagation of innovation. Greenhalgh et al. (2004) argue that there are several influences (e.g., the social network structure, homophily, opinion leaders, marketing, and formal dissemination programs) that make it possible to disseminate innovations. On the other hand, Monteiro et al. $(2014 ; 2015)$ state that affinity is an important aspect to motivate interaction between individuals. These authors proposed a theoretical model that can simulate the diffusion of knowledge in social networks using an evolutionary approach.

Accordingly, knowledge and innovation are phenomena of order, disorder, and organization in this 'Era' of telematic networks. Such phenomena are dependent on data and information that must be disseminated to generate knowledge about the subject, enabling a (re)definition of organizational actions. Such dependencies require the adoption and assimilation by individuals and organizations of a reticular behavior, i.e., interactions. Order, disorder, and organization, in the context of systems in general, are dependent on legislation, regulation, policies, management, subjects' willingness to interact, and behavioral and technological disruption (Cunha, 2014).

\section{Diffusion of knowledge, innovation, and organizational learning}

This section presents some concepts of innovation, innovation diffusion, and learning as applied 
to innovation processes. There are many concepts of innovation (Dubois \& Lins, 2012; Mattos \& Guimarães, 2012; Freitas Filho, 2013; Malik, 2014; Souza Neto et al., 2014), and a concept that aligns with our study is as follows: innovation is

[...] an invention that mitigates the various technological and market risks and reaches the market generating value for the stakeholders involved. In addition, depending on how revolutionary the innovation is and its degree of diffusion, its socioeconomic impact can be highly significant, resulting in what Schumpeter [...] called creative destruction (Carvalho, 2009, p.5, emphasis added, our translation) ${ }^{4}$.

There are many types of innovation that can be classified, for example, according to their degree of novelty (radical or incremental) (Schumpeter, 1961) and in terms of transformations in value attributes (support or rupture) (Christensen et al., 2009). Radical innovation causes great changes in the world, whereas incremental innovation promotes change in a procedural and continuous manner. Support innovation can be characterized as incremental or radical innovation and it is aimed to improve service performance, which is already known by an also known public, or seeks that the most profitable users within this public can acknowledge the technological attributes involved in service performance. Disruptive innovation involves the creation of new services, adding new value attributes According to Christensen et al. (2009), disruptive innovation has three value attributes: (1) technology training; (2) management model innovation; (3) commercial system.

Innovation is only recognized as innovation when it is adopted and disseminated within society.

Diffusion is the means by which innovation is disseminated, through market or non-market channels, from their first implementation to different consumers, countries, regions, sectors, markets, and companies. Without dissemination, an innovation has no economic impact. The minimum requirement for a change in a company's products or functions of to be considered innovation is that it is new (or significantly improved) to the company (Organização para Cooperação e Desenvolvimento Econômico/Financiadora de Estudos e Projetos, 2005, p.24, emphasis added, our translation $)^{5}$.

Diffusion and adoption of innovation have been the subject of several studies (Suriñach et al., 2009; Moreno \& Suriñach, 2014; Brem \&Viardot, 2015), including research studies on health care (United Kingdom, 2011). The conceptual model for innovation diffusion in health services, formulated by Greenhalgh et al. (2004) and discussed in this paper, consists of six steps. The third step of the model, described in the present study as communication and influence to adopt a given innovation through its diffusion and dissemination, is among the challenges of interactions between hospital managers/leaders and network coordination/governance. However, communication and influence depend on the previous two steps, denominated in the present study as "defining innovation attributes" and "adoption by individuals and assimilation by the system".

According to these British theories (Greenhalgh et al., 2004), the rate of adoption of an innovation is associated with the interactions between the innovation, its potential adopters and the context of the health service system. Greenhalgh et al. (2004) define two categories of attributes related to innovation, namely standard and key attributes. Standard attributes are required for the adoption and assimilation of complex innovations in service organizations and depend on key attributes. Both attributes explain the variations in the adoption rates of innovations in service organizations (Table 1). They are intrinsically associated with the adoption and assimilation of innovation by individuals and systems, respectively.

The attributes listed in Table 1 depend on individual adoption. In general, individuals are passive recipients of innovation and have certain characteristics

\footnotetext{
4 "[...] é uma invenção que venceu os vários riscos associados, tanto tecnológicos como de mercado, e chegou ao mercado, gerando valor para os stakeholders envolvidos. Além disso, dependen do de quão revolucionária é a inovação e de seu grau de difusão, o impacto socioeconômico pode ser de tal significativo, resultando no que Schumpeter [...] denominava de destruição criativa" (Carvalho, 2009, p.5, grifo nosso).

5 "A difusão é o meio pelo qual as inovações se disseminam, através de canais de mercado ou não, a partir da primeira introdução para diferentes consumidores, países, regiões, setores, mercados e empresas. Sem difusão uma inovação não tem impacto econômico. Aexigência mínima para que uma mudança nos produtos ou funções da empresa seja considerada uma inovação éque ela seja nova (ou significativamente melhorada) para a empresa" (Organização para Cooperação e Desenvolvimento Econômico/Financiadora de Estudos e Projetos, 2005, p.24, grifo nosso).
} 
(Greenhalgh et al., 2004). These characteristics may be summarized in a total of seven categories: (1) general psychological history (i.e., tolerance of ambiguity, intellectual ability, motivation, values, and learning style); (2) specific psychological history (i.e., motivation, values, objectives, and specific skills); (3) meaning (i.e., whether the meaning attributed to an innovation coincides with the meaning assigned by leadership, service users, and other stakeholders); (4) adoption decision, characterized as a process and not as an isolated event; (5) concerns in the pre-adoption stage (i.e., knowledge and effects of the innovation in its practice); (6) concerns during early use (i.e., continuous access to information about the innovation and training and technical support on task performance); and (7) concerns of established users (i.e., feedback to adopters on the consequences of the innovation and whether they have the opportunity, autonomy, and support to adapt the innovation to improve its intended purpose).

Individual adoption depends on the assimilation by the service organization (i.e., the system). Greenhalgh et al. (2004) describe individual adoption as emanating from a system based on an organic model, in which the assimilation of the service by the organization is characterized by a process of going back and forth between the early steps of development and implementation. In general, this process is interrupted multiple times due to shocks, setbacks, and surprises in the adoption of an innovation or innovative activity between individual steps (i.e., adoption) and organizational steps (i.e., assimilation). These steps depend on the duality of "knowledge-awareness", "assessment-choice", and "adoption-implementation" of organizational innovation in services.

Greenhalgh et al. (2004), in suggesting a conceptual model for the diffusion of innovation in health services, clarify the difference between the terms diffusion and dissemination. Dissemination is the result of active and planned efforts to persuade target groups to adopt an innovation. Diffusion is informal, unplanned, decentralized, horizontal, or negotiated among peers.

Massarani (1998), based on Pasquali (1978), presents conceptual bases for the popularization of science, differentiating among the terms diffusion, dissemination, and scientific disclosure, as follows:

a) Diffusion is sending messages developed in widely understandable codes or language;

b) Dissemination is the sending of messages developed in specialized languages, i.e., transcribed into specialized codes and restricted to selected receivers

Table 1. Innovation attributes.

\begin{tabular}{|c|c|c|c|}
\hline \multicolumn{2}{|l|}{ Standard attributes } & \multicolumn{2}{|r|}{ Key attributes } \\
\hline Relative advantage & $\begin{array}{l}\text { Are the innovations the most effective } \\
\text { or cost-effective? }\end{array}$ & Inaccurate limits & $\begin{array}{l}\text { Refers to the adoption of complex } \\
\text { innovations in service organizations; it } \\
\text { depends on products, services, or process } \\
\text { provided by otherorganizational structures. }\end{array}$ \\
\hline Compatibility & $\begin{array}{l}\text { Are the innovations compatible with } \\
\text { values, standards and requirements? }\end{array}$ & Risk & $\begin{array}{l}\text { If there is a high level of uncertainty } \\
\text { regarding the results of innovation, it is } \\
\text { unlikely to be adopted. }\end{array}$ \\
\hline Complexity & $\begin{array}{l}\text { Are the innovations reduced by praxis } \\
\text { and thus unlikely to be adopted? }\end{array}$ & Work Performance & $\begin{array}{l}\text { If innovation is practical and easy to use, it } \\
\text { is easily adopted. }\end{array}$ \\
\hline Testing & $\begin{array}{l}\text { Are the innovations experienced } \\
\text { without commitment? }\end{array}$ & Knowledge required to use & $\begin{array}{l}\text { Innovation is adopted when the knowledge } \\
\text { required to use it is encoded and } \\
\text { transferred from one context to another. }\end{array}$ \\
\hline Visibility & $\begin{array}{l}\text { Are the benefits of the innovations } \\
\text { visible? }\end{array}$ & \multirow{2}{*}{ Support } & \multirow{2}{*}{$\begin{array}{l}\text { An innovation is assimilated if the } \\
\text { technology is accompanied by a service to } \\
\text { the user, e.g., customization, training, and } \\
\text { online technical support. }\end{array}$} \\
\hline Reinvention & $\begin{array}{l}\text { Are these innovations tailored to the } \\
\text { needs of potential adopters? }\end{array}$ & & \\
\hline
\end{tabular}

Source: Adaptation of Greenhalgh et al. (2004). 
formed by specialists. It can be characterized as intrapeer (between specialists in the same area) or extrapeer (between specialists in different areas);

c) Disclosure means transcoded messages, i.e., messages are transformed into an accessible language for universal reception.

Silva and Carneiro (2006) see diffusion as a practice that involves interaction between experts and non-experts. Thus, once a managerial innovation is propagated its implementation or incorporation occurs through active and planned efforts on behalf of the management, and therefore this innovation becomes dominant in the organization. The confirmation or support of an innovation occurs when it is established as a routine and continues until its obsolescence (Greenhalgh et al., 2004).

The innovation activities of a company depend partly on the variety and structure of its relationships with sources of information, knowledge, technologies, practices, and human and financial resources. Each interaction connects the innovating firm to other actors in the innovation system: government laboratories, universities, policy departments, regulators, competitors, suppliers, and consumers (Organização para Cooperação e Desenvolvimento Econômico/Financiadora de Estudos e Projetos, 2005, p.27, emphasis added, our translation) ${ }^{6}$.

Adoption and diffusion of innovation imply an organizational learning process. Organizational learning processes are associated with the increase in the stock of knowledge to improve organizational performance and also with managerial innovation since continuing improvement is needed to generate innovation and develop individual and organizational skills. The purpose of these processes is to acquire differentiations from other organizations, competitors or not, and to enhance the sustainability of these organizations (Lastres \& Ferraz, 1999; Tidd et al., 2008; Tidd \& Bessant, 2015).

According to the Oslo Manual (Organização para Cooperação e Desenvolvimento Econômico/Financiadora de Estudos e Projetos, 2005, p.61, our translation), "an organizational innovation is the implementation of a new organizational method in the company's business practices, in the organization of the workplace or in its external relations"7.

It is widely accepted that innovation is central to the growth of the product and productivity. However, although our understanding of innovation activities and their economic impact has increased considerably since the first edition of the Manual, it remains lacking. For example, as the world economy evolves, so does the innovation process. Globalization has led companies (i.e., organizations) to dramatic crises with regard to access to information and new markets. It has also resulted in greater international competition and in new organizational forms to address global supply chains. Due to technological advantages and greater information flows, knowledge is increasingly perceived as a central driver of economic growth and innovation. However, it remains to be seen how such factors affect innovation (Organização para Cooperação e Desenvolvimento Econômico/Financiadora de Estudos e Projetos, 2005, p.15, emphasis added, our translation) $)^{8}$.

In the present study, the term organizational innovation is equivalent to management innovation in hospitals, which is understood as the adoption and incorporation of significantly changed organizational

\footnotetext{
6 "As atividades de inovação de uma empresa dependem parcialmente da variedade e da estrutura de suas relações com as fontes de informação, conhecimento, tecnologias, práticas e recursos humanos e financeiros. Cada interação conecta a firma inovadora com outros atores do sistema de inovação: laboratórios governamentais, universidades, departamentos de políticas, reguladores, competidores, fornecedores e consumidores"(Organização para Cooperação e Desenvolvimento Econômico/Financiadora de Estudos e Projetos, 2005, p 27, grifo nosso).

7 "Uma inovação organizacional é a implementação de um novo método organizacional nas práticas de negócios da empresa, na organização do seu local de trabalho ou em suas relações externas" (Organização para Cooperação e Desenvolvimento Econômico/Financiadora de Estudos e Projetos, 2005, p.61).

8 "Aceita-se amplamente que a inovação seja central para o crescimento do produto e da produtividade. Entretanto, embora nosso entendimento sobre as atividades de inovação e de seu impacto econômico tenha aumentado muito des de a primeira edição do Manual, ele ainda é deficiente. Por exemplo, assim como a economia mundial evolui, o mesmo ocorre com o processo de inovação. A globalização conduziu empresas a crises dramáticas no que diz respeito ao acesso à informação e a novos mercados. Ela também resultou em maior competição internacional e emnovas formas de organização para lidar com cadeias de fornecimento global. Devido a vantagens em tecnologias e maiores fluxos de informação, o conhecimento é cada vez mais percebido como um condutor central do crescimento econômico e da inovação. Porém, ainda não se sabe como tais fatores afetam a inovação"(Organização para Cooperação e Desenvolvimento Econômico/Financiadora de Estudos e Projetos, 2005, p.15, grifo nosso).
} 
structures, advanced management techniques, and new or substantially changed strategic guidelines (Organização para Cooperação e Desenvolvimento Econômico/ Financiadora de Estudos e Projetos, 2004, p.61).

Management innovation is related to changes in management structure, interaction between various areas, sectors, or departments, the relationship with stakeholders and various process structuring techniques. The innovation process begins with learning and the introduction of the innovation into new practices, products, designs and processes. In many situations, the innovative process can be summarized as the introduction of new technologies or technological innovations into the organizational context. The innovative process is almost always the result of interaction in that it involves agents such as organizations (i.e., firms, associations, and cooperatives), government agencies, universities, research institutes, and financial institutions (Cassiolato, 2004; Sbicca \& Pelaez, 2006; Tigre, 2006).

Organizational innovation in business practices involves the implementation of new methods for organizing routines and procedures for conducting work. It includes, for example, the implementation of new practices for improving the sharing of learning and knowledge within the company (i.e., the organization). One example is the prior implementation of practices for codifying knowledge, for example, by establishing databases with best practices, lessons and knowledge, so that they are more accessible to others. Another example is the prior implementation of practices for employee development and improvements in employee retention, such as education and training systems. Other examples include the prior introduction of management systems for general production or supply operations, such as management systems for the supply chain, business reengineering, lean production and quality management systems (Organização para Cooperação e Desenvolvimento Econômico/Financiadora de Estudos e Projetos, 2005, p.62, emphasis added, our translation) ${ }^{9}$.

In the third edition of the Oslo Manual, two factors that managers must develop to support their actions in organizational structures are highlighted, namely social or network capital and interactional evaluations.

Social or network capital refers to companies' stocks of social trust, values and standards. It has a significant impact on the information flow within a company and on knowledge sharing in collaborative activities with other organizations. Companies can implement new organizational structures or new practices to introduce a new business culture, standards and values to improve the company's capacity for innovation. The establishment of trust is also a key factor in maintaining and improving relationships within and outside the company. Long-term relationships that build mutual trust can offer benefits to all participants (Organização para Cooperação e Desenvolvimento Econômico/Financiadora de Estudos e Projetos, 2005, p.98, emphasis added, our translation) ${ }^{10}$.

Innovation has an economic impact when it is widely diffused among organizations, sectors, and regions triggering new mechanisms, processes, and projects or creating new loci in society.

Diffusion can be understood as a process by which an innovation is communicated through channels over time among members of a social system (Rogers, 2003).

\footnotetext{
9 "As inovações organizacionais em práticas de negócios compreendem a implementação de novos métodos para a organização de rotinas e procedimentos para a condução do trabalho. Isso inclui, por exemplo, a implementação de novas práticas para melhorar o compartilhamento do aprendizado e do conhecimento no interior da empresa. Um exemplo é a primeira implementação de práticas para a codificação do conhecimento, por exemplo pelo estabelecimento de bancos de dados com as melhores práticas, lições e outros conhecimentos, de modo que se tornem mais acessíveis a outros. Outro exemplo é a primeira implementação de práticas para o desenvolvimento dos empregados e melhorias na permanência do trabalhador, como os sistemas de educação e de treinamento. Outros exemplos são a primeira introdução de sistemas de gerenciamento para a produção geral ou para as operações de abastecimento, tais como sistemas de gerenciamento da cadeia de fornecedores, reengenharia de negócios, produção enxuta esistemas de gerenciamento da qualidade" (Organização para Cooperação e Desenvolvimento Econômico/Financiadora de Estudos e Projetos, 2005, p.62, grifo nosso).

10 "O capital social ou de rede refere-se aos estoques de confiança social, valores e normas das empresas. Dele decorrem importantes impactos sobre a circulação da informação dentro de uma empresa e sobre o compartilhamento de conhecimentos em atividades colaborativas com outras organizações. As empresas podem implementar novas estruturas organizacionais ou novas práticas para introduzir uma nova cultura de negócios, normas e valores, com o objetivo de melhorar a capacidade de inovar da empresa. O estabelecimento da confiançaétambém um fator-chave para a manutenção e a melhoria dos relacionamentos, dentro e fora da empresa. Os relacionamentos de longo prazo que podem construir a confiança mútua podem oferecer benefícios a todos os participantes" (Organização para Cooperação e Desenvolvimento Econômico/Financiadora de Estudos e Projetos, 2005, p.98, grifo nosso).
} 
Thus, it is appropriate to establish an organizational leadership style that addresses the importance of adopting innovation in workplace organization.

Innovation in workplace organization involves the implementation of new methods for distributing responsibilities and decision-making powers among employees in the existing division of labor within and among company (and organizational unit) activities. New concepts for the structuring of activities, such as integration of different business activities, are also included. An example of workplace innovation is the first implementation of an organizational model that gives company employees greater autonomy in decisionmaking and encourages them to contribute their ideas. This aim can be achieved through decentralization of group activities and management control or the establishment of formal or informal work teams in which individual workers have more flexible job responsibilities. However, organizational innovation may also involve the centralization of activities and greater accountability for decisionmaking (Organização para Cooperação e Desenvolvimento Econômico/Financiadora de Estudos e Projetos, 2005, p.62, emphasis added, our translation) ${ }^{11}$.

According to Souza (2000, p.25), exercising leadership today is to produce results through "internal and external bridges" to release the creativity of "human talent".

[...] leaders need to be able to obtain results from inter-company teams with diverse interests involving different companies and cultures. The ability to lead networks rather than simply command subordinates has become a differentiating ability and one that is increasingly valued [...] (Souza, 2000, p.27, our translation) ${ }^{12}$.

This author, who is a consultant and teacher, believes that a change in leaders'mentality is required to generate results "outside the walls" of organizations. This assumption requires these leaders to monitor and evaluate established interactions between organizational subjects.

The evaluation of interactions has been expanded because of the importance of knowledge flows among firms and other organizations for the development and the diffusion of innovation. This evaluation helps the understanding of the role of organizational structures and practices that promote the sharing and use of knowledge and interaction with other companies and public institutions. This process also includes the forming of closer relationships with suppliers and advancing the development of marketing practices to better reach consumers. [...] It covers a variety of interactions ranging from trade among independent information units to active involvement in joint innovation projects (Organização para Cooperação e Desenvolvimento Econômico/Financiadora de Estudos e Projetos, 2005, p.16, emphasis added, our translation) ${ }^{13}$

Greenhalgh et al. (2004) emphasize that health innovation initiatives have been relatively disadvantaged in relation to the diffusion of innovation in service organizations. It is therefore essential that innovation is diffused in health services in a planned way to maximize

\footnotetext{
11 "As inovações na organização do local de trabalho envolvem a implementação de novos métodos para distribuir responsabilidades e poder de decisão entre os empregados na divisão de trabalho existente no interior das atividades da empresa (e unidades organizacionais) e entre essas atividades. Participam também novos conceitos para a estruturação de atividades, tais como a integração de diferentes atividades de negócio. Um exemplo de inovação no local de trabalho é a primeira implementação de um modelo organizacional que confere aos empregados de uma empresa maior autonomia na tomada de decisões e os encoraja a contribuir com suas ideias. Isso pode ser alcançado por meio da descentralização das atividades de grupo e do controle gerencial ou pelo estabelecimento de times de trabalho formais ou informais nos quais trabalhadores individuais têm responsabilidades de trabalho mais flexíveis Entretanto, inovações organizacionais podem também envolver a centralização de atividades e maior responsabilidade final para a tomada de decisões" (Organização para Cooperação e Desenvolvimento Econômico/Financiadora de Estudos e Projetos, 2005, p.62, grifo nosso).

12 "[...] os líderes precisam estar capacitados para obter resultados de equipes interempresariais com diversidade de interesses, compostas de diferentes empresas e culturas envolvidas. A capacidade de liderar networks, em vez de simples comando de subordinados, passou a ser uma habilidade diferenciada e cada vez mais valorizada"(Souza, 2000, p.27).

13 "A avaliação das interações foi ampliada em virtude da importância dos fluxos de conhecimento entre as firmas e outras organizações para o desenvolvimento e a difusão de inovações. Isso ajuda a entender o papel das estruturas organizacionais e das práticas que promovem o compartilhamento e o uso do conhecimento e da interação com outras empresas e instituições públicas. Isso inclui também a formação de relacionamentos mais próximos com fornecedores e o avanço do desenvolvimento de práticas de marketing para melhor atingir os consumidores. As interações estão agora em um capítulo separado que cobre uma variedade de interações que vão das trocas entre unidades autônomas de informação ao envolvimento ativo em projetos de inovação conjuntos" (Organização para Cooperação e Desenvolvimento Econômico/Financiadora de Estudos e Projetos, 2005, p.16, grifo nosso).
} 
the exposure and scope of successful innovation in terms of behavior and possibly to induce desirable changes in administrative and health care service management.

This diffusion proceeds from learning that is intrinsically linked to the ability to innovate. Therefore, learning is conceived as something interactive, i.e., involving organizations and the cultural context, and it depends on organizational flexibility and cognitive capacity for the new knowledge to be absorbed. These attributes are essential for the diffusion of new technologies (Rogers, 2003; Sbicca \& Pelaez, 2006; Tigre, 2006).

Rogers notes that:

The decision stage in the innovation-decision process takes place when an individual (or other decision-making unit) engages in activities that lead to the choice to adopt or reject an innovation [...]. Adoption is a decision to make full use of an innovation as the best course of action available. Rejection is a decision not to adopt an innovation (Rogers, 2003, p.177, emphasis added).

According to Rogers (2003), the full use of an innovation requires a decision and, subsequently, its diffusion.

Innovation diffusion generally covers a range of activities related to the propagation of new products, technologies, processes, ideas, behaviors, etc. in social and market contexts. The issue gained momentum in Brazil in the mid-1990s, when innovation initiatives derived from agreements, exchanges, and partnerships, which then developed between companies, governments, universities, research incubators and institutions, and began requiring greater circulation of information and knowledge. This development led to a greater focus on innovation, which had hitherto been centered on strictly economic relationships between the market and industry to include variables of a social and behavioral nature. [...] Since that time, from rural sociology to marketing, innovation diffusion studies have been carried out with different approaches, concepts, and methods in a variety of disciplines and areas of expertise, including public health, geography, sociology, anthropology, communications, economics, administrative sciences, education, and psychology (Jardim, 2008, p.1456, emphasis added, our translation) ${ }^{14}$

According to this logic, innovation can only be diffused if it is first adopted. Rogers (2003) introduces a model for decision-making related to innovation, which consists of five stages: knowledge, persuasion, decision, implementation or incorporation, and confirmation or support.

1. Knowledge occurs when an individual (or other decision-making unit) is exposed to an innovation's existence and gains an understanding of how it functions.

2. Persuasion occurs when an individual (or other decision-making unit) forms a favorable or an unfavorable attitude towards the innovation.

3. Decision takes place when an individual (or other decision-making unit) engages in activities that lead to a choice to adopt or reject the innovation.

4. Implementation occurs when an individual (or other decision-making unit) puts a new idea into use.

5. Confirmation takes place when an individual seeks reinforcement of an innovation- decision already made, but he or she may reverse this previous decision if exposed to conflicting messages about the innovation (Rogers, 2003, p.169, emphasis of the author).

The characteristics of the innovation process lead to an interest in understanding interactive processes and how they operate in organizational learning. Theories of the firm seek to understand the nature of learning processes as a key component for creating an innovative agent. This agent is understood as a firm (i.e., organization)

\footnotetext{
14 "A difusão de inovações abrange genericamente uma gama de atividades relativas à propagação de novos produtos, tecnologias, processos, ideias, comportamentos etc., em contextos sociais emercadológicos. O tema ganhou impulso no Brasilem meados da década de 1990, quando as iniciativas de inovação derivadas dos convênios, intercâmbios e parcerias que então se desenvolviam entre empresas, governos, universidades, incubadoras e instituições de pesquisa começaram a requerer maior circulação de informações e de conhecimento. Esse desdobramento permitiu estender o foco do interesse pelas inovações, até então centrado nas relações estritamente econômicas entre mercado e indústria, para variáveis de natureza social e comportamental. [...] Desde então, da sociologia rural ao marketing, os estudos sobre difusão de inovações vêm se realizando com diferentes abordagens, conceitos e métodos numa variedade de disciplinas e áreas de conhecimento, entre as quais a saúde pública, geografia, sociologia, antropologia, comunicação, economia, ciências administrativas, educação e psicologia" (Jardim, 2008, p.1456, grifo nosso).
} 
that acquires skills and operates in a constantly changing environment.

\section{Methodological procedures}

This study analyzed the InovarH Network. According to Santana (2007), the InovarH Network is a technical cooperation initiative of the Pan American Health Organization (PAHO) and the Brazilian Ministry of Health, and it is focused on the quality of care provided by health system hospitals. The InovarH Network was legitimized by Ordinance no 1773 of the Brazilian Ministry of Health, on July 28, 2006, which provides technical and financial support to the structure and operation of the network (Cunha, 2012).

The central idea of InovarH Network is to create a vast and consistent network of cooperation between academic centers and hospitals that are members of the Unified Health System (government-provided health care system), to promote actions aimed at institutional qualifications through the creation and strengthening of a new management profile for the participating hospitals. This initiative seeks to overcome some difficulties: (a) lack of communication between the agents of creation of technologies, resulting from the costs associated with interaction techniques; (b) exchange of documents and messages quickly and efficiently; and (c) distribution of teaching materials.

The network activities and internet usage are key factors for the development and success of the InovarH Network (Santana, 2007). The initiative of InovarH Network is consistent with the assertion that social networks are seen as an organizational standard capable of expressing, in their relationship arrangements, innovative political and economic ideas created to solve current problems.

Social Network Analysis was applied in this study (Fritsch \& Kauffeld-Monz, 2010; Scott, 2011; 2013) using one-mode networks, in which the nodes represent entities (e.g., actors) with the same characteristics. The goal was to model the structure of the hospital organization's relationships and to observe the actors' behavior. A questionnaire was administered to 37 hospitals that make up the Network InovarH, and only
31 answered (83.7\%). One of the authors applied the questionnaire that was answered by 61 hospital staff members (82.4\%); 25 respondents occupied management positions. Three questions asked the respondents to indicate, among the 37 hospitals in the InovarH Network, those with whom they have already developed some procedures, those to whom they have asked for doubt clarification, and those from whom they have received information about successful and innovative management processes.

The questionnaire was applied to enable the modeling of the structure of the hospital organization's relationships and the actors' behavior based on three types of interaction: Type 1 (T1) - interaction in which procedures are developed (i.e., a real situation); Type 2 (T2) - interaction in which there is clarification of doubts (i.e., a trustworthy relationship characterized as a link of social capital); and Type 3 (T3) - interaction in which successful innovative management processes are shared (i.e., a desire to exchange experiences). They classify the interactions understood as collaborative relationships in organizational learning and management innovation.

The "social networks are most often composed of who knows whom or who talks to whom within a community or an organization. Network models are constructed to show how these relations influence attitudes, beliefs, and behaviors" (Valente, 2010, p.4). To establish the relationships between these organizations, two types of actor connections are modeled in two contexts: Network 1 (N1) - based on all respondents' answers; Network 2 (N2) based only on the answers of the respondents holding managerial positions (i.e., directors, coordinators, and supervisors). These two contexts generated networks for each specific type of interaction (i.e., T1N1, T1N2, T2N1, T2N2,T3N1, and T3N2).

The first context accounted for 61 respondents, and the second context included only the 25 respondents holding management positions. Thus, there were a total of six networks for analysis and discussion (i.e., three types in two contexts); in addition, the networks were considered considering all components (i.e., subgraphs are connected but are disconnected from other subgraphs, and the same networks considering only the major components). 
The following properties were therefore calculated: average degree, density, average clustering coefficient, and minimum average path. The average degree is defined by $\langle\mathrm{k}\rangle=\sum_{i=1}^{n} k_{i}$, where $n$ is the number of nodes in the network, and $k_{i}$ is the degree of node $i$. Density is defined as $\Delta=\frac{2 \times m}{n \times(n-1)}$, where $m$ is the number of edges, and $n$ is the number of nodes in the network (Newman, 2010). The average clustering

coefficient is defined as $C=\frac{1}{n} \times \sum_{i=1}^{n} C_{i}$, where $n$ is the number of nodes in the network and is defined by $C_{i}=\frac{\text { number_of_pairs_of_connected_neighbors }}{\frac{1}{2} \times k_{i} \times\left(k_{i}-1\right)}$, and $k_{i}$ is the degree of node $i$ (Watts \& Strogatz, 1998). The minimum average path is defined by $L=\frac{1}{n \times(n-1)} \times \sum_{i \neq j}^{n} d(i, j)$, where $n$ is the number of nodes in the network, and $d(i, j)$ is the geodesic distance between nodes $i$ and $j$ (Newman, 2010).

\section{Results and Discussion}

Social Network Analysis metrics can reveal relationships between organizations, such as who are the most active members of a network or those who are disconnected from the majority of members. SNA is an adequate tool for monitoring and evaluating the connections between hospitals. In this study, some metrics that indicate, for example, the density of the network, the average minimal path length, etc. were used.
The Average Clustering Coefficient (C) values found are as follows: in the networks T1N1 and T1 N2, 0.14 and 0.09; in T2N1 and T2N2, 0.38 and 0.34; and in T3N1 and T3N2, 0.43 and 0.38 , respectively. These results demonstrate a low level of dissemination, ranging from 0.09 to 0.43 , indicating that the hospital network investigated is not consolidated as a network with high dissemination. This result reflects that hospital organizations in both analyzed contexts showed low willingness to cooperate and to receive and provide information. Consequently, the interaction between these hospitals in horizontal structures is low. These results are consistent with results previously found in interviews, which highlighted the need for policies to promote the flow of data and information and to encourage hospital network components to exchange their innovative processes (Cunha, 2012).

Regarding the Minimum Average Path ( $\mathrm{L}$ ), the results found for T1 N1 and T1N2 were 2.5 and 2.54; for T2N1 and T2N2, 2.15 and 2.23; and for T3N1 and T3N2, 2.20 and 2.09, respectively. These values show that the network structure promotes interaction and therefore the flow of interaction despite the low dissemination demonstrated by the Average Clustering Coefficient (C). The average degrees $(\langle k\rangle)$ of the networks show the number of hospitals (i.e., from 3 to 6 hospitals, in this case) with which the hospitals studied interacts (Table 2). This result reinforces the perception of low dissemination in the investigated Network (Cunha, 2012).

As for network density $(\Delta)$, the results reveal that the networks T1N1 and T1N2 have densities of 0.04 and 0.03. These results are low compared to those of other networks. Again, the values found indicate weak

Table 2. Network Initial Properties ó nodes $(n=|V|)$, edges $(m=|E|)$, largest component, average clustering Coefficient $(C)$, average minimum path length $(L)$, average degree $(\langle k\rangle)$, density $(\Delta)$.

\begin{tabular}{|c|c|c|c|c|c|c|c|c|}
\hline Type & Context & $n=|V|$ & $m=|E|$ & Largest component (\%) & C & L & $\langle k\rangle$ & $\Delta$ \\
\hline \multirow{2}{*}{ T1 } & N1 & 37 & 60 & 30 & 0.14 & 2.50 & 3.24 & 0.04 \\
\hline & N2 & 37 & 51 & 29 & 0.09 & 2.54 & 2.76 & 0.03 \\
\hline \multirow{2}{*}{$\mathrm{T} 2$} & N1 & 37 & 108 & 32 & 0.38 & 2.15 & 5.84 & 0.08 \\
\hline & N2 & 37 & 99 & 32 & 0.34 & 2.23 & 5.35 & 0.07 \\
\hline \multirow{2}{*}{ T3 } & N1 & 37 & 116 & 31 & 0.43 & 2.20 & 6.27 & 0.09 \\
\hline & N2 & 37 & 105 & 31 & 0.38 & 2.09 & 5.68 & 0.08 \\
\hline
\end{tabular}

Source: Cunha (2012). 
interactions between hospitals although the network's Average Minimum Path Length suggests a structure favorable to interaction. There is therefore a gap between the potential for interaction, demonstrated by the network's Average Minimum Path Length and the weakness of the real interaction, demonstrated by the average clustering coefficient and density. In other words, the hospital network analyzed has the potential to become a network of interconnecting parts. In addition, it appears that awareness on the part of hospital managers regarding strengthening the links between hospitals and developing formal and informal network diffusion programs can contribute to forming partnerships as information transfer mechanisms.

The vertices (i.e., hospitals) show that there are many variations in the average minimum path length, which indicates that every new possibility of interaction between hospitals requires few links with other network members. There is an environment where links between hospitals tend to remain stable, which may be explained by the fact that they are health care providers (i.e., members of the SUS).

According to Figures $1 \mathrm{~A}$ and $1 \mathrm{~B}$, it appears that actors $\mathrm{H}_{28}, \mathrm{H}_{26}$ and $\mathrm{H}_{35}$ have the greatest number of established connections with the other actors in terms of the development of innovative procedures. This fact highlights the importance and advantage of these hospitals in comparison to the other members of the InovarH Network in terms of collaboration in managerial processes.

It can be seen that actor $\mathbf{H}_{\mathbf{2 8}}$ establishes partnerships with seven other hospital organizations (i.e., $k=7)$. The results also show that actors $\mathbf{H}_{\mathbf{1 2}^{\prime}} \mathbf{H}_{15^{\prime}} \mathbf{H}_{19^{\prime}} \mathbf{H}_{20^{\prime}}$ $\mathbf{H}_{21}, \mathbf{H}_{22}$ and $\mathbf{H}_{33}$ are disconnected and do not appear to develop procedures with any hospital organization, nor are they sought out by any hospital for this purpose.

Figures $2 \mathrm{~A}$ and $2 \mathrm{~B}$ show the graphs of type 2 network modeling ó clarifying doubts (i.e., receiving information) in contexts 1 and 2.

The hospital organizations that are most frequently contacted to provide information were $\mathbf{H}_{26}$ followed by $\mathbf{H}_{28}$ and $\mathbf{H}_{16}$, which demonstrates the confidence of other hospitals in these three organizations. The actors $\mathbf{H}_{\mathbf{4}^{\prime}} \mathbf{H}_{\mathbf{1 9 ^ { \prime }}} \mathbf{H}_{\mathbf{2 0}}, \mathbf{H}_{\mathbf{2} \mathbf{1}^{\prime}}$ and $\mathbf{H}_{\mathbf{2 4}}$ are disconnected, revealing an absence of social capital ties among the hospitals that make up the hospital network under review.
A

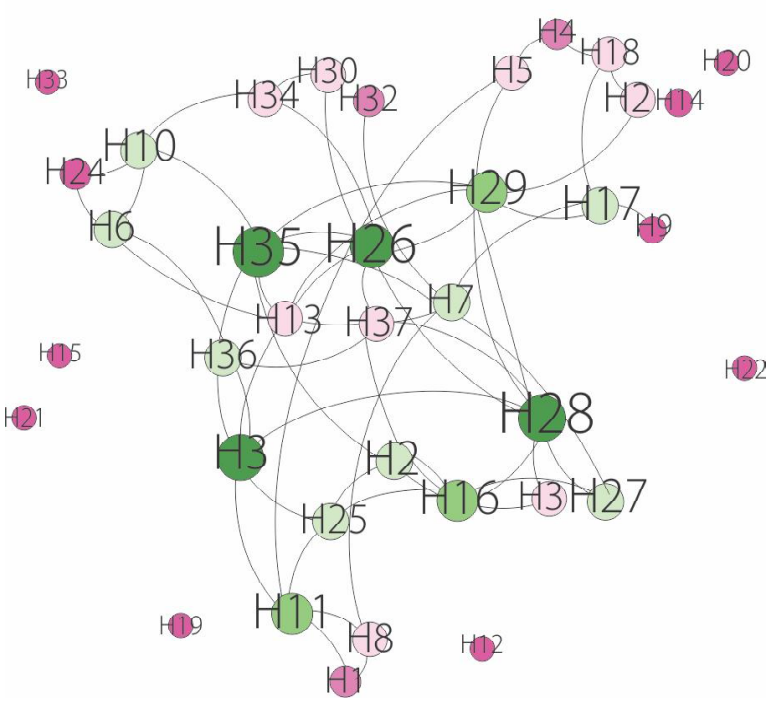

B

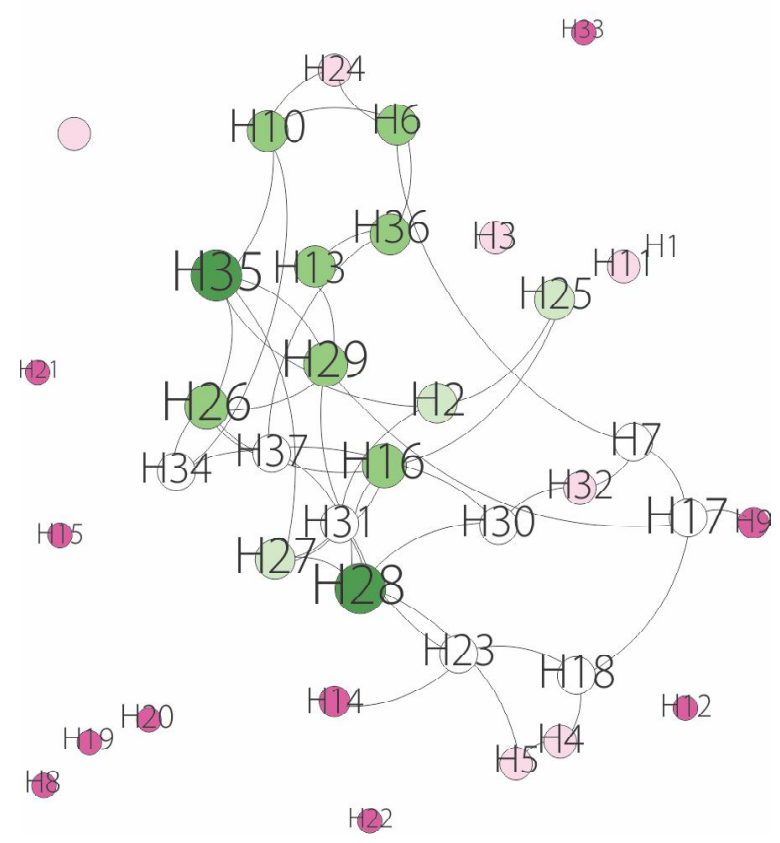

Figure 1. Graph of Network Type $1 \Leftrightarrow$ Collaboration: (A) Context $1 \Leftrightarrow$ All respondents; (B) Context $2 \Leftrightarrow$ Managers.

Source: Developed by the authors in 2015, based on a survey study conducted in 2012. 

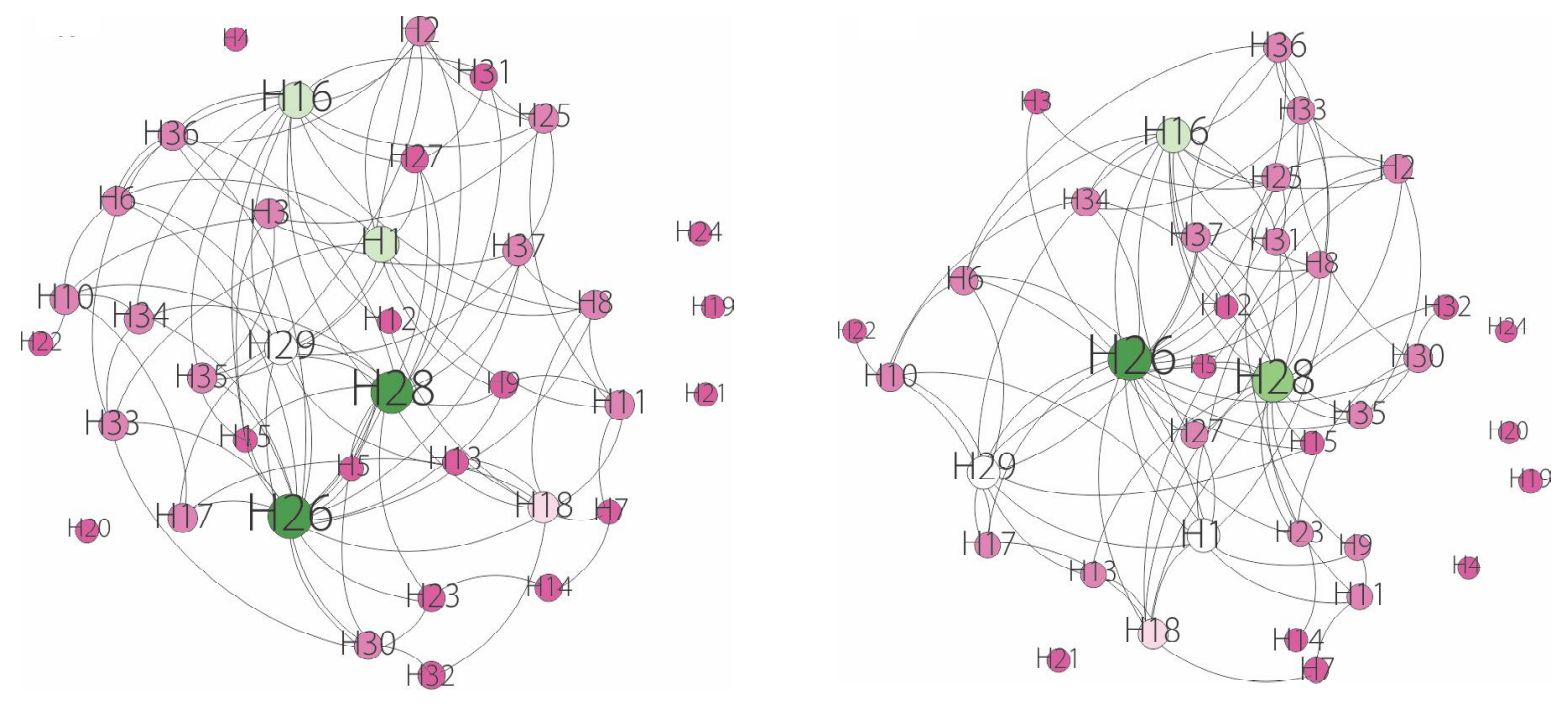

Figure 2. Graph of Network Type $2 \Leftrightarrow \Leftrightarrow$ Receiving Information: (A) Context $1 \Leftrightarrow$ All respondents; (B) Context $2 \Leftrightarrow$ Managers. Source: Developed by the authors in 2015, based on a survey study conducted in 2012.

A

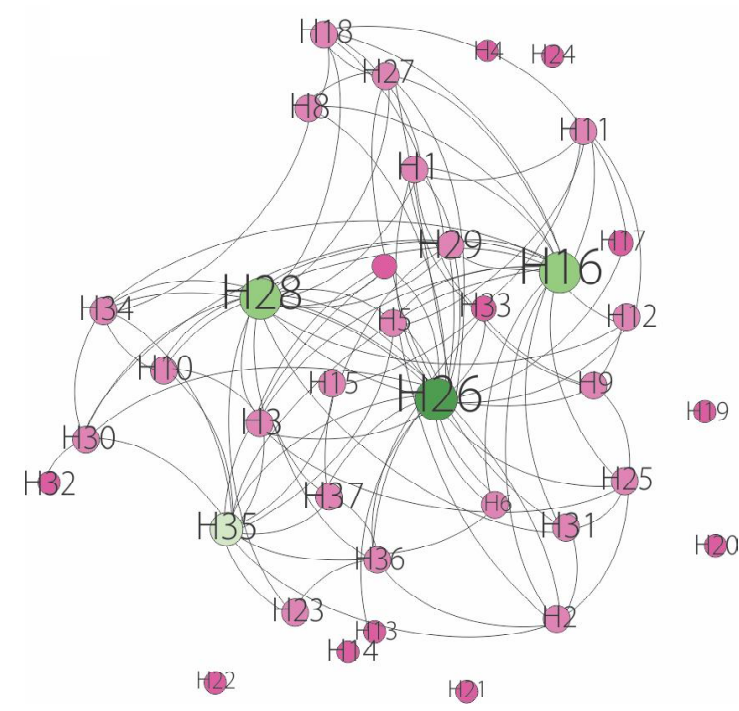

B

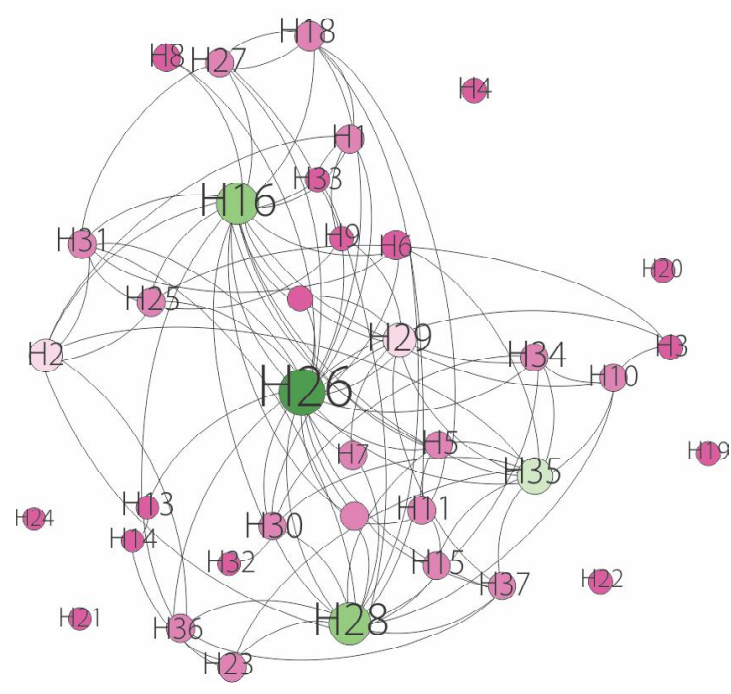

Figure 3. Graph of Network Type $3 \Leftrightarrow$ Providing Information: (A) Context $1 \Leftrightarrow$ All respondents; (B) Context $2 \Leftrightarrow$ Managers. Source: Developed by the authors in 2015, based on a survey study conducted in 2012.

Figures $3 \mathrm{~A}$ and $3 \mathrm{~B}$ show the graphs of Type 3 network modeling sharing successful innovative management processes (i.e., providing information). The graphs show that the hospitals $\mathbf{H}_{16^{\prime}} \mathbf{H}_{26^{\prime}}$ and $\mathbf{H}_{28}$ are the ones that the other hospital network members would like to share management information with. In contrast, 
no organization in the hospital network showed interest in sharing procedures with the hospitals $\mathbf{H}_{\mathbf{4}^{\prime}} \mathbf{H}_{\mathbf{1 9 ^ { \prime }}} \mathbf{H}_{\mathbf{2 0}}, \mathbf{H}_{\mathbf{2 1}}$ $\mathbf{H}_{22^{\prime}}$ and $\mathbf{H}_{24}$

\section{Conclusion}

According to the objectives proposed in this study, the results show that it is possible to adopt SNA as a tool to measure, monitor, and evaluate the socio and organizational networks created from the InovarH Network. The identification of hospitals with which the majority of the InovarH Network members would likely develop procedures, for example, is a key information for the network management in terms of sharing good health care practices. Furthermore, the identification of the hospitals that are disconnected from all other network members in terms of developing procedures stimulates and helps decision-makers to plan actions that effectively integrate all members. Thus, the SNA metrics showed that it is possible to provide relevant information about the network for decision-making in order to promote managerial innovation.

The present study showed that for the successful application of the hospital network's principles in the network management and, by extension, in the SUS, it is necessary adoption and assimilation of a new habitus, i.e., interaction, by the subjects and consequently by the organizations. This new habitus cannot be dissociated from the horizontal expansion of connections between organizations. This expansion phenomenon characterizes

\section{References}

Brem, A.; Viardot, E. (Org.). Adoption of innovation: Balancing internal and external stakeholders in the marketing of innovation. New York: Springer International Publishing, 2015.

Carvalho, M.M. Inovação: estratégias e comunidades de conhecimento. São Paulo: Atlas, 2009.

Cassiolato, J.E. Interação, aprendizado e cooperação tecnológica. Rio de Janeiro: Ricyt, 2004.

Christensen, C.M.; Grossman, J.H.; Hwang, J. Inovação na gestão da saúde: a receita para reduzir custos e aumentar qualidade. Porto Alegre: Bookman, 2009.

Cunha, F.J.A.P. Da adesão à participação em uma rede de hospitais como promoção da aprendizagem organizacional e dissemination, thereby constituting a morphology in the network: a structuring or organizing principle of the SUS.

The potential of SNA as a monitoring tool was confirmed, notwithstanding the consequences for the modeled networks. However, further investigation is recommended to identify the importance of the hospitals $\mathbf{H}_{\mathbf{1 6}}, \mathbf{H}_{\mathbf{2 6}}, \mathbf{H}_{\mathbf{2 8}}$, and $\mathbf{H}_{\mathbf{3 5}}$ as intermediaries in the communication between other hospitals. Such an investigation would be justified because the greater the participation of the hospital in the geodesics among other actors in the network, the greater its importance as an intermediary in these links. This aspect was not investigated in this study because the main objective was to identify the scope (i.e., minimum average path) and dissemination (i.e., clustering coefficient) of the investigated hospital network structure.

As shown by the SNA metrics, there is weak interaction between these organizations and a lack of cohesion within their network, which indicates the need for policies to promote the flow of data and information and openness in the investigated network components to foster the exchange of innovative processes. Stronger interactions between these hospitals in horizontal and disseminated structures have yet to be stimulated, established, incorporated, and developed by individuals, institutions, and health service organizations.

\section{Contributors}

All authors conceived, designed, performed the experiments, analyzed the data, and wrote the paper. da inovação gerencial: um olhar sobre a Rede InovarH-BA. 2012. Tese (Doutorado Multi-institucional e Multidisciplinar em Difusão do Conhecimento) - Faculdade de Educação, Universidade Federal da Bahia, Salvador, 2012.

Cunha, F.J.A.P. O complexus do conhecimento, inovação e comunicação em serviços de atenção à saúde. In: Cunha, F.J.A. P.; Lázaro, C.P.; Pereira, H.B.B. (Org.). Conhecimento, inovação e comunicação em serviços de saúde. Salvador: EDUFBA, 2014. p.221-236.

Dubois, R.; Lins, J. Inovação na gestão pública. São Paulo: Saint Paul, 2012.

Freitas Filho, F.L. Gestão da inovação: teoria e prática para implantação. São Paulo: Atlas, 2013. 
Fritsch, M.; Kauffeld-Monz, M. The impact of network structure on knowledge transfer: An application of social network analysis in the context of regional innovation networks. Annals of Regional Science, v.44, p.21-38, 2010.

Greenhalgh, T. et al. Diffusion of innovations in service organizations: Systematic review and recommendations. The Milbank Quarterly, v.82, n.4, 2004, p.581-629, 2004.

Jardim, J.B. Diffusion of innovations in health service organisations: A systematic literature review. Cadernos de Saúde Pública, v.24, n.6, p.1456-1459, 2008.

Lastres, H.M.M.; Ferraz, J.C. Economia da informação, do conhecimento e do aprendizado. In: Lastres, H.M.M.; Albagli, S. (Org.). Informação e globalização na era do conhecimento. Rio de Janeiro: Campus, 1999. p.27-57.

Malik, A.M. Gestão da inovação em serviços de atenção à saúde. In: Cunha, F.J.A.P.; Lázaro, C.P.; Pereira, H.B.B. (Org.). Conhecimento, inovação e comunicação em serviços de saúde. Salvador: EDUFBA, 2014. p.111-131.

Massarani, L. A divulgação científica no Rio de Janeiro: algumas reflexões sobre a década de 20. 1998. Dissertação (Mestrado em Ciência da Informação) - Instituto Brasileiro de Informação em Ciência e Tecnologia, Universidade Federal do Rio de Janeiro, Rio de Janeiro, 1998.

Matheus, R.F.; Silva, A.B.O. Fundamentação básica para a análise de redes sociais: conceitos, metodologia e modelagem matemática. In: Población, D.; Mugnaini, R.; Ramos, L.M.S.V. Redes sociais e colaborativas: em informações científicas. São Paulo: Angellara, 2009. p.239-287.

Mattos, J.R.L.; Guimarães, L.S. Gestão, tecnologia e inovação. São Paulo: Saraiva, 2012

Mattelart, A.; Mattelart, M. História das teorias da comunicação. 6.ed. São Paulo: Edições Loyola, 2003.

Monteiro, R.L.S. et al. An affinity-based evolutionary model of diffusion of knowledge. Journal of Communication and Technology, v.9, p.44-57, 2015

Monteiro, R.L.S. et al. Evolution based on chromosome affinity from a network perspective. Physica. A, v.403, p.276-283, 2014.

Moreno, R.; Suriñach, J. Innovation adoption and productivity growth: Evidence for Europe. Research Institute of Applied Economics: Working Paper, n.13, p.1-32, 2014. Available from: <http://www.ub.edu/irea/working_papers/2014/2014 13.pdf>. Cited: May 9, 2016.

Newman, M.E.J. Networks: An introduction. Oxford: Oxford University Press, 2010.

Organização para Cooperação e Desenvolvimento Econômico/Financiadora de Estudos e Projetos. Manual de Os/o. Rio de Janeiro: Finep, 2004. Disponível em: <http://download. finep.gov.br/imprensa/manual_de_oslo.pdf $>$. Acesso em: 9 maio 2016.

Organização para Cooperação e Desenvolvimento Econômico/Financiadora de Estudos e Projetos. Manual de Oslo: diretrizes para a coleta e interpretação de dados sobre inovação. 3.ed. Rio de Janeiro: Finep, 2005.
Pasquali, A.P. Compreender la comunicación. Caracas: Monte Ávila Editores, 1978.

Rogers, E.M. Diffusion of innovations. 5.ed. New York: Free Press, 2003

Santana, J.P. Rede de Inovação e aprendizagem em gestão hospitalar: concepção e desafios. In: Congreso Internacional del CLAD sobre la Reforma del Estado y de la Administración Pública, 12., 2007, Santo Domingo. Anais... Santo Domingo: CLAD, 2007. p.83-84.

Sbicca, A.; Pelaez, V. Sistemas de inovação. In: Pelaez, V.i Szmrecsányi, T. (Org.). Economia da inovação tecnológica. São Paulo: Hucitec, 2006. p.415-448.

Schumpeter, J.A. Teoria do desenvolvimento econômico. Rio de Janeiro: Fundo de Cultura, 1961

Scott, J. Social network analysis. 3rd. ed. London: Sage, 2013.

Scott, J. Social network analysis: Developments, advances, and prospects. Social Networks, v.1, p.21-26, 2011.

Senge, P. A quinta disciplina: arte e prática da organização que aprende. São Paulo: Best Seller, 2010.

Silva, M.R.; Carneiro, M.H.S. Popularização da ciência: análise de uma situação não formal de ensino. In: Reunião Anual da Associação Nacional de Pós-Graduação e Pesquisa em Educação, 29., 2006, Caxambu. Anais... Caxambu: Anped, 2006. p.1-16. Disponível em: <http://29reuniao.anped.org.br/ trabalhos/trabalho/GT16-2664-Int.pdf>. Acesso em: 13 jul. 2016.

Souza, C. Talentos e competitividade. Rio de Janeiro: Qualitymark, 2000.

Souza Neto, J.; Orlandi, T.R.C.; Santos, D.L.N. Inovação: estratégia, gestão e cultura. [S.I: s.n.], 2014. (e-Book Kindle).

Suriñach, J. et al. The diffusion/adoption of innovation in the internal market: Economic papers 384. Brussels: European Commission, 2009. Available from: <https://ideas.repec.org/ p/euf/ecopap/0384.html>. Cited: May 9, 2016.

Tidd, J.; Bessant, J.; Pavitt, K. Gestão da inovação. 3.ed. Porto Alegre: Bookman, 2008.

Tidd, J.; Bessant, J. Gestão da inovação. 5.ed. Porto Alegre: Bookman, 2015.

Tigre, P. Gestão da inovação: a economia da tecnologia no Brasil. Rio de Janeiro: Elsevier, 2006.

United Kingdom. Department of Health. Innovation, health and wealth: Accelerating adoption and diffusion in the NHS. London: UK Department of Health, 2011. Available from: <http://webarchive.nationalarchives.gov.uk/201301 071053 54/http:/www.dh.gov.uk/prod_consum_dh/groups/ dh_digitalassets/documents/digitalasset/dh_134597.pdf>. Cited: May 9, 2016.

Valente, T.W. Social networks and health: Models, methods, and applications. New York: Oxford University Press, 2010.

Watts, D.J.; Strogatz, S.H. Collective dynamics of small-world networks. Nature, n.393, p.440-442, 1998. 